\title{
KAJIAN BERBAGAI JEVIS PAKAN TERHADAP PERTUMBUHAN BENIH IKAN CUPANG BAGAN (Betta imbellis var. Sumatraensis)
}

\author{
Asniati, IGA Manik W dan Supriyono Eko Wardoyo* \\ -FMIPA-Universitas Nusa Bangsa Bogor \\ Jl. KH Soleh Iskandar KM 4 Cimanggu Tanah Sareal Bogor 16166 \\ Email : supriyono.wardoyo@yahoo.com
}

\section{ABSTRACT \\ Study on the Vurious Types of Feed on Fish Seed Growth of Betta Fish (Betta imbellis var. Sumatraensis)}

\begin{abstract}
Feeding a nanual feed of warms (Tubifex op, and water fleas (Daplatia sp.) combined with artificial feed is an alternative to increasing the number of omamental fish weight. The purpose of this staily was to determine the opes of nutaral feed of wuter fleas, worms and artificial feed or feed mitrares of natural and artificial feed that gived the best effect on the growth of betta - fist seed. The sasdy was conducted at the Laboratory of Biology, Factily of Natural Science University of Nusa Banga Bogar. Statistical desigi of the research was experimental with completely randomited design (CRD) consisting of 5 treatments and 3 replications. Types of natrural food te Daphnia sp., Tubifex $\$$. and artificial feed (cnumbs). Each treament used betta fivh swed of 20 jar. Treatment began feeding she seed aged 30 days to 58 dayz oll. The feed az mary as $4 \%$ of the biomass and was alministernd 3 times datily at $08: 00,12: 00$ and $16: 00$. All foctors otlier thas the type of feed grven were the same condition on each seament. A treatment that was fed with artificial feed topes (crumb) was dane from the beginutug to the end of the oxperiment. Trearment $B$ is fed Tubtfer sp was done from the beginning to the end of the apperiment. Treatment C is fed Daphinia op was dome from the beginuing to the end of the cxperiment. Treatnent $D$ wus fid Tubifex up was done for 2 weeks, then given artificial feed until the end of the experment. Treament $E$ is fed Daplina sp. for 2 weeks, then given artificial feed until the end of the experunent. Statistically various opes of feed significantly had different effect on the growth of the fish seed (P

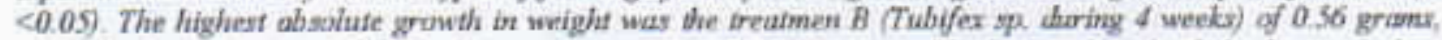
whic the lowest treament $C$ (Daphnia sp. during 4 weeks) 0.21 grams. The highest iength of absolute growth in treatment $E$ (Daphata sp, for 2 ireeks-artificial feed for 2 weeks) was $0.50 \mathrm{~cm}$. Lowest lang growth was treatment A (artficial diebs for 4 weeka) wax $0.43 \mathrm{~cm}$. Fish seed sarvival ranged from $92 \%-975$. Water quality meastared at day time shenved temperanure values from 24.5 to $27.50 \mathrm{C}$ and a pH of 5.90 to 6.48 .
\end{abstract}

Keywards : Feed, betta fish, growth, seed.

\begin{abstract}
ABSTRAK
Pemberian pakan alami berupa cacing rambut (Tubifex sp) dan kutu air (Dapiana sp) dapat dikombinasikan dengan pakan buatan merupakan altematif untuk meningkatian jumiah berat ikan hias cuparg. Tujuan penelitian ini adalah untuk mengetahui jenis pakan alami kutu air, cacing rambut dan pakan buatan, serta campuran pakan alami dan pakan buatan yang memberikan penganuh terbaik terhadap pertumbuhan berih ikan cupang. Penelitian dilakulan di Laboratorium Biologi, Fakultas MIPA, UNB, Bogor. Penelitian bersifat experimental (peroobaan) dengan Ramaugan Acak Lengkap (RAL) terdiri dari 5 perlakaun dun 3 ulangan. Jeris pakan alami yaitu Daphnia sp. dan Tuhifex sp dan pakan batan crumble (remah). Tiap petlakuan digumakan berih ikan cupang sebanyak 20 ekor/stoples. Perlakman pernberian pakan dimulai sejak benih berumur 30 hari hingga benmur 58 hari. Pakan yang diberikan sebaryak $4 \%$ dari biomassa dan diberikan 3 kali schari yaitu pukal 08.00, 12.00 dan 16,00. Semma faktor selain jenis pakan yumg diberikan, dikondisiban sama pada tiap periakuan. Petlakuan A yaitu benih diberi pakan buatan jenis eramble (remah) dari awal sampai akhir peroobaan Pedakuan B yaitu diberi pakan Tubifex sp. dari awal sampai akhir percobaan. Perlakuan C yuitu diberi pakan Daplenta sp. dari nwal sampai akhir percobaan. Periakuan D yaitu diberi pakan Tubifex sp. sctarma 2 ningegu bemuifun diberi pukan buatan sampa abdir perobban. Periakuan E yuitu diberi pakan Duphnia sp. selama 2 minggu, kemudian diberi pukan buatan sampat akhir percobaan. Pemberian berbagai jenis pakan memberikan pengaruh beda nyata tethadap pertumbuhan benih cupang $(\mathrm{P}<0,05)$. Pertumbuhan berat mullak tertingegi yakni pada benih yang diberi periakman B (Tubifex sp, selama 4 minggu) sebesar 0.56 gram, sedangkan yang terendah yakni pada benih yang diberi perlakuan C (Duplonia sp selama 4 minggu) sebesar 0.21 gram Pertumbuhan panjang mullak tetinggi yaitu pada berih yasg diberi perlakuan E (Dophnia sp.) selanta 2 minggu - pakan buatan seluma 2 minggu) sebesar $0.80 \mathrm{~cm}$. Pertumbutran panjang terendah yaitu pada benih yang diberi petakuan $A$ (pakan buatan selarna 4 minggn) scbesar $0,43 \mathrm{~cm}$. Sintasan benih cnpang berkisar antana $92 \%-97 \%$. Kualitas uir yang diukur pada siang hari menunjukkan nilai suhu $24,5-27,50 \mathrm{C}$ dan pH $5,90-6,48$
\end{abstract}

Kata kunci : Pakan, ikun cupurge, pertumbuhur, bemih 


\section{PENDAHULUAN}

Ikan Cupang adalah salah satu jenis ikan hias air tawar yang bernilai ckonomis tinggi dan banyak digemari oleh masyarakat berbagai lapisan. Ikan ini digemari karena keindahan wama dan bentuk tubuh serta memiliki sifat suka berkelahi secara alami. Selain itu, pemeliharaannya sangat mudah dan dapat ditempatkan pada tempat atau wadah yang airnya terbatas. Hal ini disebabkan ikan cupang memiliki labirin scbagai alat pernapasan tambahan, sehingga mampu mengambil oksigen secara langsung dari udara (Atmadjaja, 2009).

Sorgeloos dan Lavens (1996) menyatakan bahwa keberhasilan budidaya ikan pada suatu unit pembenihan tidak hanya ditentukan oleh teknik budidaya tetapi juga oleh produksi dan penggunaan pakan alami sebagai pakan untuk perkembangan larva dan benih. Menurut Bachtiar (2003), masalah klasik yang sering menghantui pembudidaya ikan adalah tingginya tingkat kematian benih. Hal ini disebabkan benih sering mendapat pakan yang tidak sesuai dengan alat peneernaan dan ukuran mulutnya. Akibatnya, benih sering mati sebelum mencapai fase remaja. Faktor itulah yang kemudian menimbulkan opini di kalangan pembudidaya ikan bahwa fase pembenihan adalah fase kritis. Jika fase ini tidak ditangani dengan baik, resiko kegagalan budidaya ikan akan cukup tinggi, karena itu, untuk mempertahankan kelangsungan hidupnya, benih ikan membutuhkan jenis pakan yang tepat.

Hasil penelitian Pusat Penclitian
dan Pengembangan Perikanan
(Puslitbangkan), pakan yang tepat untuk benih ikan adalah pakan alami. Karena pakan alami tidak hanya mudah dicema oleh benih, tetapi kandungan gizinya yang cukup tinggi. Ironisnya, ketersediaan pakan alami tidak mampu memasok kebutuhan industri ikan hias air tawar karena keterbatasan jumlah pakan alami di alam (Bachtiar, 2003). Pakan alami seperti cacing rambut (Tubifex sp.) ketersediannya masih tergantung di alam dan kutu air (Daphnia sp.) yang harus dikultur.
Pemberian cacing rambut dan kutu air. Di kombinasikan dengan pakan buata merupakan alternatif untuk meningkatkan ketersediaan jumlah pakan.

Berdasarkan uraian di atas, maka periu diadakan penelitian untuk mengetahui pertumbuhan benih ikan cupang pada berbagai jenis pakan, baik pakan alami, pakan buatan, maupun campuran dari pakan alami dengan pakan buatan schingga didapatkan jenis pakan yang terbaik. Dengan demikian, hasil penelitian tersebut dapat diaplikasikan dalam manajemen pakan sehingga dapat meningkatkan efektifitas dan efisiensi produksi dalam budidaya ikan cupang.

Manfaat dari penelitian ini adalah dapat memberikan informasi kepada para pembenih ikan cupang tentang jenis pakan yang paling optimal bagi pertumbuhan benih ikan eupang. Hipotesis $\left(\mathrm{H}_{0}\right)=$ Tidak ada pengaruh pemberian berbagai jenis pakan terhadap pertumbuhan berih ikan cupang. Hipotesis $\left(\mathrm{H}_{1}\right)=$ Ada pengaruh pemberian berbagai jenis pakan terhadap pertumbuhan benih ikan cupang.

Tujuan penelitian ini adalah untuk mengetahui jenis - jenis pakan mana yang memberikan pengaruh terbaik terhadap pertumbuhan benih ikan eupang.

\section{BAHAN DAN METODE}

\section{Bahan dan Alat}

Bahan percobaan yang digunakan terdiri dari benih ikan cupang bagan berumur 30 hari yang diperoleh dari peternak ikan hias di daerah Jalan Baru, Desa Kukupu, Kota Bogor (Lampiran 6). Pakan alami kutu air (Daphnia sp) berupa kutu air beku, pakan alami lain cacing rambut (Tubifex sp.) hasil tangkapan dari alam (Lampiran 7) dan pakan buatan jenis crumble (remah) merk Feng $\mathrm{Li}$ yang memiliki kandungan kadar protein minimal $40 \%$, kadar lemak $5 \%$, kadar serat kasar $3 \%$, dan kadar abu maksimal $16 \%$. Lebih jauh bahan pakan buatan peneltian tersebut dapat di lihat pada Lampiran 8. Peralatan yang diperlukan selama penelitian adalah akuarium, stoples plastik ( $5 \mathrm{~L})$, acrator, 
jangka sorong, timbangan analitik, thermometer dan $\mathrm{pH}-$ meter.

\section{Metode Penelitian}

Penelitian yang dilakukan adalah bersifat experimental (percobaan). Rancangan yang digunakan adalah Rancangan Acak Lengkap (RAL) dengan 5 perlakuan dan 3 ulangan. Perlakuan yang diberikan berupa pemberian jenis pakan alami yaitu Daphnia sp. dan Tubifex sp. dan pakan buatan remah. Pada tiap perlakuan digunakan benih ikan cupang sebanyak 20 ekoristoples. Perlakuan pemberian pakan dimulai sejak benih berumur 30 hari sampai benih berumur 58 hari. Semua faktor selain jenis pakan yang diberikan, dikondisikan sama pada tiap perlakuan. Mendasari penelitian scbelumnya yang dilakukan oleh Nursyams (2003), maka perlakuan penelitian ini dilakukan sebagai berikut :

\begin{tabular}{|c|c|}
\hline A & $\begin{array}{l}\text { benih diberi pakan } \\
\text { buatan jenis crimble } \\
\text { (remah) dari awal sampai } \\
\text { akhir percobaan. }\end{array}$ \\
\hline al: & $\begin{array}{l}\text { beriih diberi pakan } \\
\text { Tubifex sp. dari awal } \\
\text { sampai akhir percobaan. }\end{array}$ \\
\hline alakuan C : & $\begin{array}{l}\text { benih diberi pakan } \\
\text { Daphnia sp. dari awal } \\
\text { sampai akhir percobaan. }\end{array}$ \\
\hline $\mathrm{D}$. & $\begin{array}{l}\text { benih diberi pakan } \\
\text { Tubifex sp. selama } 2 \\
\text { minggu, kemudian diberi } \\
\text { pakan buatan sampai } \\
\text { akhir percobaan. }\end{array}$ \\
\hline D & $\begin{array}{l}\text { benih diberi pakan } \\
\text { Daphnia sp. selama } 2 \\
\text { minggu, kemudian diberi } \\
\text { pakan buatan sampai } \\
\text { akhir percobaan. }\end{array}$ \\
\hline alak & 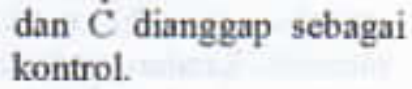 \\
\hline
\end{tabular}

\section{Cara Kerja}

Cara kerja pada penelitian ini adalah menyiapkan lima belas buah stoples plastik bersih dengan ukuran $5 \mathrm{~L}$. Stoples plastik diisi sebanyak $3,5 \mathrm{~L}$ air yang sudah diacrasi kurang lebih selama 24 jam. Benih cupang bagan sebanyak kurang lebih 350 ekor diadaptasikan dulu selama tiga hari di dalam akuarium pada lingkungan laboratorium sebelum dilakukan percobaan. Benih cupang bagan yang sudah diadaptasikan ditebar ke dalam stoples plastik dengan padat pencbaran 20 ekor/ stoples. Benih cupang bagan diberikan pakan sebanyak $4 \%$ dari berat total badannya (Biomassa), Pakan diberikan kepada Benih eupang bagan sebanyak 3 kali sehari, yaitu pukul 08.00 , 12.00 , dan 16.00. Perubahan jenis pakan dilakukan setelah 2 minggu masa penelitian (khusus untuk perlakuan D dan E). Wadah pemeliharaan disipon setiap hari untuk membuang kotoran dan sisa pakan yang mengendap di dasar stoples dengan menggunakan selang kecil dan diisi lagi air sesuai volume sebelumnya. Sampling penimbangan berat benih dan pengukuran panjang benih dilakukan setiap minggu.

\section{Parameter yang Diamati}

\section{Pertumbuhan}

Fujaya (1994) menyatakan bahwa pertumbuhan dalam dinamika populasi ikan diidefinisikan sebagai pertambahan panjang dan bobot ikan dalam satuan tertentu. Faktor yang mempengaruhi pertumbuhan ikan antara lain, keturunan, jenis kelamin dan umur, serta kerentanan penyakit. Keturunan berhubungan dengan cara scleksi induk, yaitu induk yang bermutu tentu menghasilkan anakan yang lebih baik atau sebaliknya.

Pada pemeliharaan ikan ini kualitas air, kepadatan ikan, serta jumlah dan kualitas pakan pun harus selalu diperhatikan. Kepadatan ikan sangat penting untuk kenyamanan hidup ikan. Jumlah ikan yang terialu padat dapat menimbulkan stress karena kualitas air cepat menjadi jelek dan oksigen terlarut eepat habis. Jumlah dan kualitas pakan merupakan faktor penting, bila pakannya terlalu sedikit, ikan akan sukar tumbuh. Scbaliknya, bila terlala banyak memberikan pakan, kondisi air menjadi 
jelek, terutama jika memberikan pakan buatan (Lesmana dan Dermawan, 2001).

\section{Pertumbuhan Berat}

Berat benih ditimbang ketika pertama kali benih diperoleh (umur 30 hari). Sampling penimbangan berat benih dilakukan setiap benih berumur kelipatan 1 minggu dan terakhir pada waktu benih berumur 58 hari. Setiap sampling berat diambil 4 benih cupang secara acak pada tiap ulangan. Cara menimbang berat benih dengan menggunakan timbangan analitik. Pertumbuhan berat mutlak dihitung dengan menggunakan persamaan (Weatherley, 1972) berikut :

$\mathrm{W}_{\mathrm{m}}=\mathrm{W}_{\mathrm{t}}-\mathrm{W}_{\mathrm{e}}$

Keterangan: $\mathrm{W}_{\mathrm{m}}=$ pertumbuhan mutlak (g)

$W_{1}=$ berat rata - rata pada waktu $t(\mathrm{~g})$

$\mathrm{W}_{0}=$ berat rata - rata pada awal (g)

\section{Pertum buhan Panjang}

Panjang benih diukur ketika pertama kali benih diperoleh (umur 30 hari). Sampling pengukuran panjang benih dilakukan setiap benih berumur kelipatan 1 minggu dan terakhir pada waktu benih berumur 58 hari. Setiap sampling panjang tubuh diambil 4 benih cupang secara acak pada tiap ulangan. Cara mengukur panjang benih adalah dengan menggunakan jangka sorong. Pertumbuhan panjang mutlak dihitung dengan menggunakan persamaan berikut (Weatherley, 1972).

$P_{m}=P_{t}-P_{0}$

$$
\text { Keterangan: } \begin{aligned}
\mathrm{P}_{\mathrm{m}} & =\begin{array}{l}
\text { pertumbuhan mutlak } \\
(\mathrm{cm})
\end{array} \\
\mathrm{P}_{\mathrm{t}} & =\begin{array}{l}
\text { panjang rata }- \text { rata } \\
\text { pada waktu } \mathrm{t}(\mathrm{cm})
\end{array} \\
\mathrm{P}_{0}= & \begin{array}{l}
\text { panjang rata }- \text { rata } \\
\text { pada awal }(\mathrm{cm})
\end{array}
\end{aligned}
$$

\section{Hubungan Panjang dan Berat}

Hubungan panjang dan berat dihitung untuk melihat kecenderungan pertumbuhan dari benih cupang. Jika pertumbuhan panjang dan berat seimbang đisebut pertumbuhan Isometrik dan jika tidak scimbang disebut pertumbuhan allometrik. Rumus untuk menganalisis hubungan panjang dan berat benih adalah :

$$
W=a L^{b}
$$

$$
\text { Keterangan: } \begin{aligned}
\mathrm{W} & =\text { berat ikan }(\mathrm{g}) \\
\mathrm{L} & =\text { panjang total ikan } \\
\mathrm{A} & =\text { intersep } \\
\mathrm{B} & =\text { koefisien regresi }
\end{aligned}
$$

Nilai $b$ yang mungkin timbul adalah $b<3, b=3, b>3$. Bila nilai $b<3$ berarti pertumbuhan panjang ikan lebih dominan dari pertumbuhan beratnya. Bila $b=3$ berarti pertumbuhan panjang dan berat ikan seimbang. Bila $b>3$ berarti pertumbuhan berat ikan lebih dominan dari pertumbuhan panjangnya.

\section{Sintasan}

Menurut Effendi (2003), sintasan adalah perbandingan jumlah organisme yang hidup pada akhir suatu periode dengan jumlah organisme yang hidup pada awal periode. Sintasan ikan dipengaruhi oleh beberapa faktor diantaranya adalah kualitas air, ketersediaan pakan yang sesuai dengan kebutuhan ikan dan padat penebaran. Sintasan dapai digunakan untuk mengetahui toleransi dan kemampuan ikan untuk hidup. Kelangsungan hidup bagi ikan budidaya dapat dikatakan baik apabila jumlah ikan hidup mencapai $80-90 \%$.

Kematian ikan dapat disebabkan oleh beberapa faktor antara lain tidak mampu beradaptasi dengan lingkungan, tidak mampu menghindar dari serangan predator, terkena penyakit, kompetisi antar spesies, umur, kondisi abiotik, parasit, dan kurangnya ketersediaan pakan (Lesmana dan Dermawan, 2001). 
Sintasan dihitung dengan mengggunakan rumus Effendi (2003), yaitu

$$
\mathrm{S}=\frac{\mathrm{N} t}{N_{0}} \times 100 \%
$$

$$
\text { Keterangan: } \begin{aligned}
\mathrm{S} & =\begin{array}{l}
\text { persentase sintasan } \\
\text { ikan }(\%)
\end{array} \\
\mathrm{Nt} & =\begin{array}{l}
\text { jumlah ikan akhir } \\
\text { penelitian (ekor) }
\end{array} \\
\mathrm{No} & =\begin{array}{l}
\text { jumlah ikan awal } \\
\text { penclitian (ekor) }
\end{array}
\end{aligned}
$$

\section{Kualitas Air}

Air atau media pemeliharaan merupakan faktor utama untuk kehidupan ikan. Air secara alami merupakan pelarut yang sangat baik schingga hampir semua material dapat larut di dalamnya (Lesmana dan Dermawan, 2001). Keberhasilan budidaya ikan ditentukan oleh keberhasilan dalam pengelolaan air, baik dari segi kuantitas maupun kualitas air. Bebcrapa parameter kualitas air untuk budidaya ikan air tawar terbagi menjadi 2 yaitu faktor fisika air yang terdiri dari temperatur/suhu air, kecerahan dan kekeruhan air. Sedangkan faktor kimia air meliputi kadar oksigen terlarut, derajat keasaman, kadar amonia $(\mathrm{NH})$, kadar karbondioksida $\left(\mathrm{CO}_{2}\right)$, kadar Nitrogen $\left.\mathrm{NO}_{2}\right)$ terlarut, alkalinitas dan kesadahan total (Ciptanto, 2010).

Pengamatan dan pengukuran parameter kualitas air media pemeliharaan dilakukan setiap minggu pada siang hari antara jam $10.00-1200$. Parameter yang diukur meliputi suhu dan $\mathrm{pH}$.

\section{Analisis Data}

Data hasil pengamatan selama percobaan dianalisis menggunakan Rancangan Acak Lengkap dengan model persamaan Steel dan Torrie (1991) :

$Y_{0}=\mu+\tau_{1}+\varepsilon_{00}$
Keterangan: $Y_{i j}=$ nilai pengamatan periakuan ke-I pada ulangan ke-j

$\mu=$ nilai tengah populasi

$\tau_{1}=$ pengaruh periakuan ke-i

$\varepsilon_{i j}=$ pengaruh galat percobaan dari perlakuan ke-I, ulangan $k e-j$

Data disajikan secara deskriptif dalam bentuk tabel dan grafik. Pengaruh perbedaan antar perlakuan terhadap pertumbuhan mutlak (panjang dan berat tubuh) diuji dengan analisis ragam (ANOVA) pada selang kepercayaan 95\% Uji lanjutan yang digunakan bila uji $\mathrm{F}$ memberi hasil berbeda nyata adalah uji BNJ (Steel dan Torric, 1991).

Tabel 1. Parameter kualitas air yang diukur selama penelitian

\begin{tabular}{llll}
\hline No & Parameter & Satuan & $\begin{array}{l}\text { Alat/ } \\
\text { Metode }\end{array}$ \\
\hline 1 & Suhu & "C & Termometer \\
2 & $\mathrm{pH}$ & Unit & pH-meter \\
\hline
\end{tabular}

\section{HASIL DAN PEMBAHASAN}

Pertumbuhan Berat Mutlak Benih Cupang Bagan (Betta imbellis var. Sumatraensis)

Data hasil pengamatan pertumbuhan berat mutlak benih cupang bagan dapat dilihat pada lampiran 1 . Grafik pertumbuhan berat mutlak benih cupang bagan (Betta imbellis var. Sumatraensis) dapat dilihat pada gambar 8 .

Hasil pengamatan dan analisis data pertumbuhan berat mutlak benih diantara ketiga kontrol menunjukkan pertumbuhan berat mutlak tertinggi yakni pada benih yang diberi perlakuan B (Tubifex sp. selama 4 minggu) sebesar $0,56 \mathrm{~g}$, sedangkan yang terendah yalni pada benih yang diberi perlakuan C (Daphnia sp. selama 4 minggu) sebesar $0,21 \mathrm{~g}$ (Lampiran 1 Gambar 1). Hal ini diduga 
karena pakan alami jenis Tubifex sp. memiliki kandungan nutrisi yang lebih baik daripada Daphnia sp. dan pakan buatan. Tubifex sp. memiliki kandungan protein lebih tinggi yaitu $57 \%$ sedangkan Daphnia sp.hanya $42,66 \%$ dan pakan buatan $40 \%$ (Lesmana dan Dermawan, 2001). Pada umur di atas 4 minggu benih cupang sangat membutuhkan pakan yang mengandung protein tinggi. Selain itu, Tubifex sp, cocok diberikan kepada benih cupang yang berumur di atas 30 hari, sedangkan Daphnia sp. cocok diberikan pada benih cupang yang berumur 7 - 30 hari, (Atmadjaja, 2009).

Perlakuan D (Tubifex sp. selama 2 minggu dan pakan buatan selama 2 minggu) dan E (Dapinia sp. selama 2 minggu dan pakan buatan selama 2 minggu) yang menunjukkan hasil pertumbuhan berat tertinggi adalah pada perlakuan E yaitu $0,44 \mathrm{~g}$. Hal ini diduga karena pada perlakuan D terjadi penurunan nafsu makan benih cupang. Benih cupang yang diberikan pakan alami Tubifex sp. selama 2 minggu terlihat lebih lahap dalam mengkonsumsi pakan, namun setelah 2 minggu diganti dengan memberikan pakan buatan, benih cupang kurang lahap dalam mengkonsumsi pakan (Lampiran 1 Gambar 1). Benih cupang mungkin lebih menyukai pakan Tubifex sp. karena pakan Tubifex sp. lebih menarik dari segi penampakan dan aromanya. Kemungkinan lainnya adalah benih cupang tidak mampu mencerna pakan buatan serta formula pakan buatan tersebut menghasilkan penampakan, aroma, tekstur dan cita rasa yang kurang disukai ikan,
(Afrianto dan Liviawaty, 2005). Rendahnya daya cerna ikan terhadap pakan buatan yang diberikan cukup merugikan, tidak hanya bagi ikan yang dipelihara, tctapi juga bagi kualitas lingkungan. Pada perlakuan E (Daphnia sp. selama 2 minggu dan pakan buatan selama 2 minggu) tidak terlihat penurunan nafsu makan benih schingga angka pertumbuhannya pun semakin tinggi tiap minggunya. Hal ini diduga karena penampakan Daphnia sp. hampir sama dengan kenampakan pakan buatan. Pakan alami Daphnia sp. berupa frozen Daphnia sp. (Daphnia sp. beku) dimana Daphnia sp. sudah tidak dalam keadaan hidup seperti pakan Tubifex sp., sehingga ketika diganti dengan pakan buatan tidak terlihat penurunan nafsu makan.

Perlakuan ketiga kontrol dengan perlakuan D (Tubifex sp, sclama 2 minggu dan pakan buatan sclama 2 minggu) dan perlakuan E (Daphnia sp.selama 2 minggu dan pakan buatan selama 2 minggu) yang menunjukkan hasil pertumbuhan berat tertinggi adalah pada perlakuan B (Tubifex sp. selama 4 minggu) yaitu $0,56 \mathrm{~g}$. Hasil yang menunjukkan pertumbuhan berat mutlak tertinggi kedua adalah pada perlakuan E (Daphnia sp.selama 2 minggu dan pakan buatan selama 2 minggu) yaitu $0,44 \mathrm{~g}$. Hal ini menunjukkan bahwa benih yang diberikan beberapa perlakuan, tetap pakan alami yang memberikan hasil pertumbuhan berat mutlak terbaik. Pakan alami terbaik yang bisa diberikan kepada benih cupang umur $30-58$ hari adalah jenis Tubifex sp. dan Daphnia sp. yang dikombinasikan dengan pakan buatan.

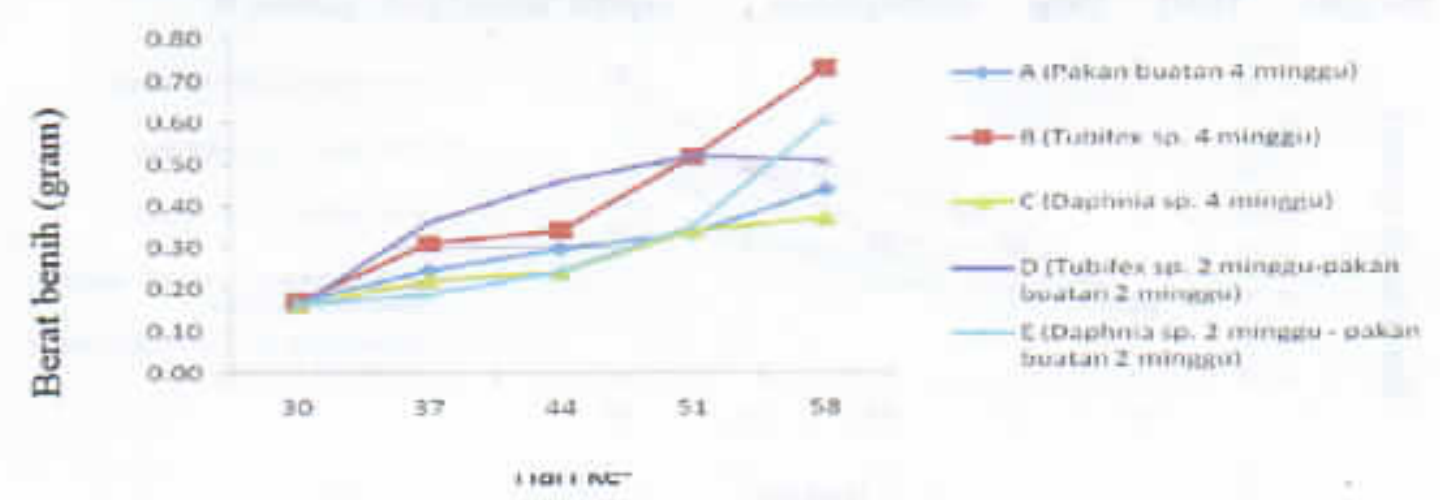

Gambar 1. Grafik pertumbuhan berat mutlak benih cupang bagan 
Kelebihan pakan alami selain tidak menurunkan kualitas air, tidak mudah rusak, dan mudah dicema ikan, ternyata baik juga untuk kualitas wama pada benih. Benih cupang yang diberikan pakan alami Tubifex sp. bisa memberikan wama pada tubuh benih disaat benih cupang berumur di atas 2 bulan. Benih cupang yang diberikan pakan alami Daphnia sp. bisa memberikan warna pada tubuh benih disaat benih cupang berumur di atas 3 bulan (Lampiran 1 Gambar 1).

Hasil uji ANOVA menunjukkan bahwa pemberian berbagai jenis pakan terhadap pertumbuhan berat mutlak benih cupang bagan terdapat pengaruh beda sangat nyata $(\mathrm{P}<0,01)$. $\mathrm{Uji}$ ANOVA pertumbuhan berat mutlak benih cupang dapat dilihat pada lampiran 6 dan uji BNJ dapat dilihat pada lampiran 2 .

Hasil uji BNJ (Beda Nyata Jujur) menunjukkan bahwa beberapa perlakuan jenis pakan berpengaruh sangat nyata terhadap pertumbuhan berat mutlak benih cupang bagan $(\alpha<0,01)$ yaitu antara perlakuan A (pakan buatan selama 4 minggu) dan B (Tubifex sp. selama 4 minggu), antara perlakuan B (Tubifex sp. selama 4 minggu) dan C (Daphnia sp. selama 4 minggu), serta antara perlakuan $C$ (Daphnia sp. selama 4 minggu) dan E (Daphnia sp. selama 2 minggu dan pakan buatan selama 2 minggu). Perlakuan beberapa jenis pakan yang berpengaruh nyata torhadap pertumbuhan berat mutlak benih cupang bagan $(\alpha<0,05)$ adalah antara perlakuan B (Tubifex sp. selama 4 minggu) dan D (Tubifex sp. sclama 2 minggu dan pakan buatan selama 2 minggu). Hasil yang menunjukkan beberapa perlakuan jenis pakan yang berpengaruh tidak nyata $(\alpha>0,05)$ yaitu antara perlakuan $A$ (pakan buatan selama 4 minggu) dan $C$ (Daphnia sp. selama 4 minggu), antara perlakuan A (pakan buatan selama 4 minggu) dan D (Tubifex sp. selama 2 minggu dan pakan buatan selama 2 minggu), antara perlakuan A (pakan buatan selama 4 minggu) dan E (Daphinia sp. selama 2 minggu dan pakan buatan selama 2 minggu), antara perlakuan B (Tubifex sp. selama 4 minggu) dan E (Daphnia sp. selama 2 minggu dan pakan buatan selama 2 minggu), antara perlakuan $C$ (Daphnia sp. selama 4 minggu) dan $D$ (Tubifex sp. selama 2 minggu dan pakan buatan sclama 2 minggu), dan antara periakuan D (Tubifex sp. selama 2 minggu dan pakan buatan selama 2 minggu) dan $\mathrm{E}$ (Daphnia sp. selama 2 minggu dan pakan buatan selama 2 minggu (Lampiran 2 ).

Perlakuan B (Tubifex sp. selama 4 minggu) dan E (Daphnia sp. selama 2 minggu dan pakan buatan selama 2 minggu) tidak berpengaruh nyata kemungkinan karena benih cupang menyukai pakan alami Tubifex sp. dan juga pakan alami Daphnia sp. yang dikombinasikan dengan pakan buatan.

Perțmbuhan Panjang Mutlak Benih Cupang Bagan (Betta imbellis var. Sumatraensis)

Data pertumbuhan panjang mutlak benih cupang bagan ditunjukkan pada lampiran 3 dan Gambar 2. Grafik pertumbuhan panjang mutlak benih cupang bagan (Betta imbellis var. Sumatraensis) seperti terlihat pada gambar 9 .

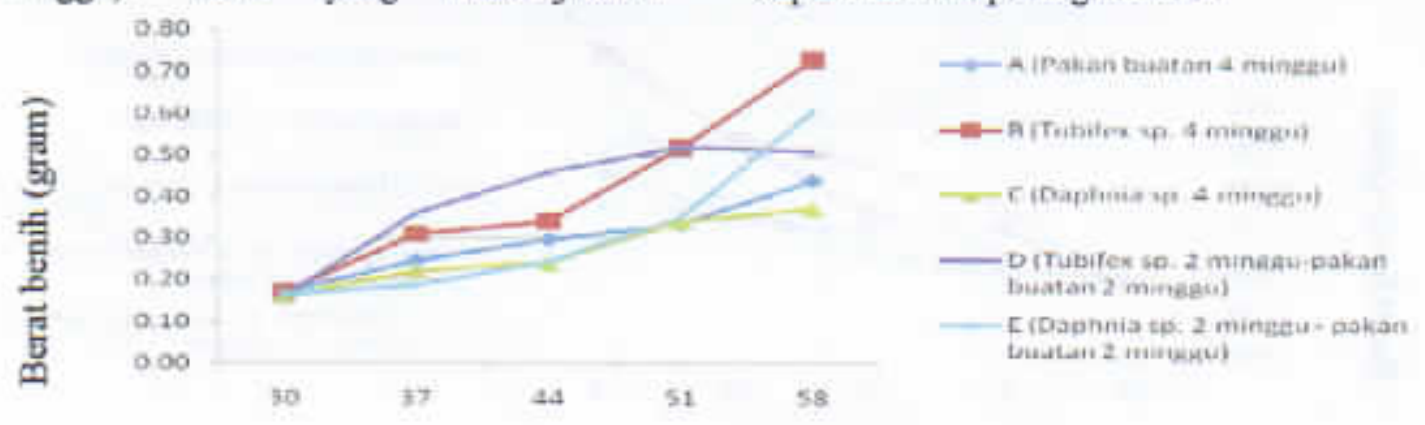

Hari ke-

Gambar 2. Grafik Pertumbuhan Panjang Mutlak Benih Cupang Bagan 
Hasil pengamatan dan analisis data pertumbuhan panjang mutlak benih diantara ketiga kontrol menunjukkan pertumbuhan panjang mutlak tertinggi yakni pada benih yang diberi perlakuan B (Tubifex sp. selama 4 minggu) yaitu 0,78 $\mathrm{cm}$, sedangkan yang terendah adalah pada perlakuan A (pakan buatan selama 4 minggu) yaitu $0,43 \mathrm{~cm}$. Hal ini diduga karena pakan alami jenis Tubifex sp. memiliki kandungan nutrisi yang lebih baik daripada pakan buatan. Kemungkinan lain adalah benih cupang tidak mampu mencerna pakan buatan dengan baik serta formula pakan buatan tersebut menghasilkan kenampakan, aroma, tekstur dan citarasa yang kurang disukai benih ikan (Afrianto dan Liviawaty, 2005).

Perlakuan D (Tubifex sp. selama 2 minggu dan pakan buatan sclama 2 minggu) dengan perlakuan $\mathrm{E}$ (Daphia sp. selama 2 minggu dan pakan buatan selama 2 minggu) menunjukkan pertumbuhan panjang tertinggi yaitu pada benih yang diberi perlakuan E yaitu $0,80 \mathrm{~cm}$. Hal ini diduga karena terjadi penurunan nafsu makan benih pada periakuan D. Benih cupang yang dibcrikan pakan alami Tubtfex sp. selama 2 minggu terlihat lebih lahap dalam mengkonsumsi pakan dibandingkan setelah 2 minggu terakhir masa percobaan benih kurang begitu lahap dalam mengkonsumsi pakan buatan. Pada perlakuan E (Daphnia sp. selama 2 minggu dan pakan buatan selama 2 minggu) tidak terlihat penurunan nafsu makan pada benih.

Perlakuan ketiga kontrol dan perlakuan D (Tubifex sp. selama 2 minggu dan pakan buatan selama 2 minggu) dan perlakuan E (Daphnia sp. selama 2 minggu dan pakan bualan selama 2 minggu) yang menunjukkan hasil pertumbuhan panjang tertinggi adalah pada perlakuan E (Daphnia sp. selama 2 minggu dan pakan buatan selama 2 minggu) yaitu $0,80 \mathrm{~cm}$. Hal ini karena Daphnia sp. yang diberikan tidak mengalami penurunan nilai nutrisi meskipun dicampur dengan pakan buatan. Seluruh bagian tubuh Daphnia sp. dimangsa secara utuh oleh benih cupang. Enzim-enzim pencernaan yang ada dalam tubuh Daphimia sp. akan berfungsi sebagai biokatalisator yang akan menimbulkan autokatalisis pada dirinya sendiri. Enzim tersebut membantu benih cupang untuk mencerna secara kescluruhan kandungan nutrisi yang terkandung dalam Daphnia sp. Hal ini tentu saja akan menurunkan kebutuhan energi metabolisme untuk menguraikan bahan makanan. Ikan cupang sebagaimana ikan kamivora lainnya mempunyai enzim chitinase yang dapat mencerna cangkang tubuh Daphnia sp. Dari uraian di atas, terlihat bahwa pakan Daphnia sp. yang dicampur dengan pakan buatan mampu menghasilkan pertumbuhan panjang optimal dibandingkan dengan benih yang hanya diberikan pakan buatan (Lampiran 3 dan Gambar2).

Hasil uji ANOVA menunjukkan bahwa pemberian berbagai jenis pakan terhadap pertumbuhan panjang mutlak benih cupang bagan terdapat pengaruh beda nyata $(a<0,05)$. Uji ANOVA pertumbuhan panjang mutlak benih cupang dapat ditihat pada lampiran 9 dan uji BNJ dapat dilihat pada lampiran 4.

Hasil uji BNJ menunjukkan bahwa perlakuan berbagai jenis pakan berpengaruh nyata terhadap pertumbuhan panjang mutlak benih cupang bagan $(\mathrm{P}<$ 0,05 ). Perbedaan nyata terjadi antara perlakuan A (Pakan buatan selama 4 minggu) dan E (Daphnia sp. selama 2 minggu dan pakan buatan selama 2 minggu). Benih pada perlakuan $\mathrm{A}$ menunjukkan pertumbuhan panjang mutlak sebesar $0,43 \mathrm{~cm}$ sodangkan perlakwan E sebesar $0,80 \mathrm{~cm}$. Perbedaan ini diduga karena perbedaan kandungan nutrisi dalam pakan. Benih cupang tidak cukup memenuhi kandungan nutrisi jika hanya diberikan pakan buatan.

\section{Hubungan Pertumbuhan Berat dan Panjang Benih Cupang Bagan (Betta imbellis var. Sumatraensis)}

Berdasarkan perhitungan antara panjang dan berat rata-rata selama penelitian, diperoleh bahwa setiap perlakuan memiliki kecenderungan pola pertumbuhan yang sama yaitu allometrik negatif $(b<3)$ yang berarti bahwa pertumbuhan panjang rata-rata lebih cepat 
dibandingkan dengan pertumbuhan berat rata-rata. Hubungan panjang dan berat benih cupang yang diberi perlakuan A (Pakan buatan 4 minggu) meningkat mengikuti persamaan regresi linear $\bar{Y}=$ $0.491 x-0.923$. Perlakuan B (Tubifex sp. 4 minggu) meningkat mengikuti persamaan regresi lincar $\mathrm{Y}=0.637 \mathrm{x}-1.288$. Perlakuan C (Daphmia sp. 1 bulan) meningkat mengikuti persamaan regresi linear $\mathrm{Y}=0.308 \mathrm{x}-0.580$. Perlakuan $\mathrm{D}$ (Tubifex sp. 2 minggu-pakan buatan 2 minggu) meningkat mengikuti persamaan regresi linear $\mathrm{X}=0.565 \mathrm{x}-1.172$. Perlakuan E (Daphinta sp. 2 minggu-pakan buatan 2 minggu) meningkat mengikuti persamaan regresi linear $\mathrm{Y}=0.522 \mathrm{x}$ 1.028. Data hubungan panjang dan berat benih cupang bagan setiap minggu pengamatan selama penelitian digambarkan dalam grafik pada Lampiran 5 dan Gambar 3.
Dari hasil analisis hubungan panjang dan bobot sclama penelitian, diperoleh kecenderungan pola pertumbuhan yang sama yaitu allometrik negatif dengan nilai $b<3$ yang berarti bahwa pertumbuhan panjang rata-rata ikan Iebih cepat dibandingkan dengan pertumbuhan berat rata - rata ikan. Nilai ini menunjukkan keadaan biologis ikan dan secara komersil mempunyai arti kualitas pada ikan. Namun untuk perdagangan ikan hias, panjang lebih diutamakan menjadi parameter ukuran ikan.

\section{Sintasan Benih Cupang Bagan (Betta imbellis var. Sumatraensis)}

Data sintasan benih cupang bagan ditunjukkan pada tabel 2 .

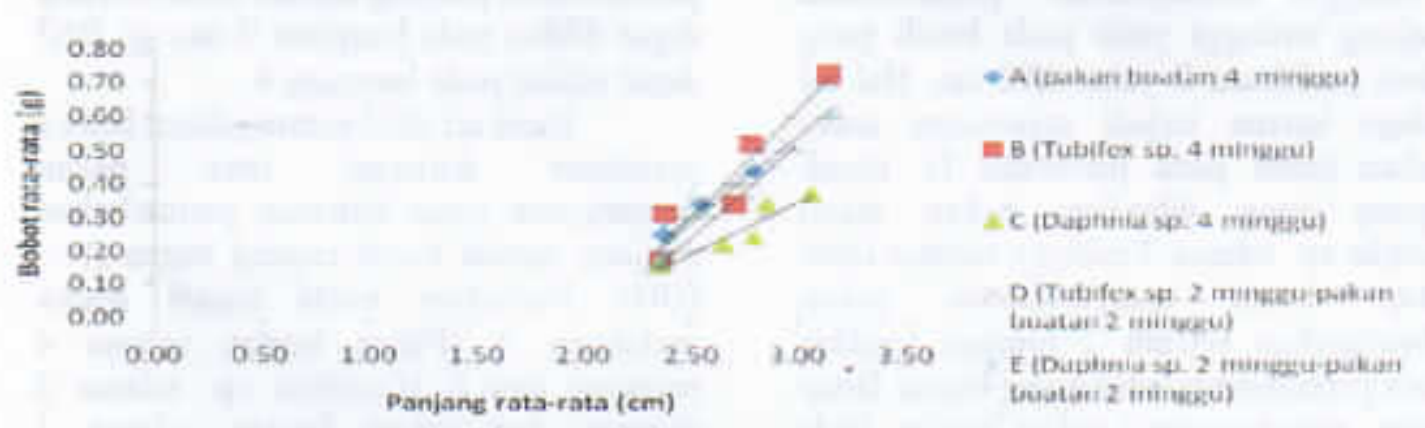

Gambar 3. Grafik Hubungan Panjang dan Berat Tubuh Benih Cupang Bagan

Tabel 2. Sintasan Benih Cupang Bagan (Betta imbellis var. Sumatraensis) selama Penelitian (\%)

\begin{tabular}{|c|c|c|c|c|}
\hline \multirow[t]{2}{*}{ Perlakuan } & \multicolumn{3}{|c|}{$\begin{array}{l}\text { Sintasan }(\%) \\
\text { Per ulangan }\end{array}$} & \multirow{2}{*}{$\begin{array}{l}\text { Rata-rata } \\
\text { Sintasan }(96)\end{array}$} \\
\hline & 1 & 2 & 3 & \\
\hline $\begin{array}{l}\text { A } \\
\text { (Pakan buatan selama } 4 \text { minggu) }\end{array}$ & 100 & 85 & 90 & 92 \\
\hline (Tubifex sp. selama 4 minggu) & 100 & 100 & 90 & 97 \\
\hline $\begin{array}{l}\text { (Daphnia sp. selama } 4 \text { minggu) } \\
\text { D }\end{array}$ & 100 & 85 & 100 & 95 \\
\hline $\begin{array}{l}\text { (Tubifex sp. selama } 2 \text { minggu dan } \\
\text { pakan buatan selama } 2 \text { minggu) } \\
\mathrm{E} \\
\text { (Daphnia } \text { sp. selama } 2 \text { minggu dan }\end{array}$ & 100 & 90 & 90 & 93 \\
\hline pakan buatan selama 2 minggu) & 100 & 80 & 100 & 93 \\
\hline
\end{tabular}


Hasil pengamatan dan analisis data sintasan benih cupang bagan menunjukkan sintasan tertinggi pertama yakni pada benih yang diberi perlakuan B (Tubifex sp. selama 4 minggu) sebesar $97 \%$, sintasan tertinggi kedua yakni pada benih yang diberi perlakuan C (Daphnia sp. selama 4 minggu) sebesar $95 \%$, sedangkan yang terendah yakni pada benih yang diberi perlakuan A (pakan buatan sclama 4 minggu) sebesar $92 \%$.

Nilai sintasan benih ikan cupang pada tiap perlakuan berada dalam kisaran yang sangat baik. Menurut Effendi (2003), kelangsungan hidup bagi ikan budidaya dapat dikatakan baik apabila jumlah ikan hidup mencapai $80-90 \%$. Sintasan ikan diduga dipengaruhi oleh beberapa faktor diantaranya adalah karena penyakit atau handling (penanganan) selama penclitian. Lesmana dan Dermawan (2001) menyatakan bahwa kematian ikan dapat discbabkan olch beberapa faktor antara lain tidak mampu beradaptasi dengan lingkungan di alam, tidak mampu menghindar dari serangan predator, terkena penyakit, kompetisi antar spesies, umur, kondisi abiotik, parasit, dan kurangnya ketersediaan pakan.

\section{Kualitas Air}

Hasil pengukuran kualitas air selama penelitian berada dalam kisaran normal yang dapat mendukung pertumbuhan benih cupang bagan. Suhu air selama penelitian berkisar anlara 24,5 $27,5^{\circ} \mathrm{C}$, sedangkan $\mathrm{pH} 5,78-6,48$.

Faktor lingkungan juga mempengaruhi tingginya pertumbuhan mutlak benih cupang bagan. Hasil pengukuran suhu sebesar $24,5-27,5^{\circ} \mathrm{C}$ pada semua perlakuan menunjukkan nilai suhu berada pada kisaran normal untuk pertumbuhan benih eupang. Sesuai pendapat Atmadjaja (2009), suhu air yang dapat menunjang pertumbuhan cupang berkisar antara $24-30^{\circ} \mathrm{C}$. Menurut Boyd (1990) dalam Septyani (2009), suhu dapat mempengaruhi aktivitas penting ikan terutama untuk pernapasan, pertumbuhan dan reproduksi. Suhu juga dapat mempengaruhi kejenuhan pada air dalam menyerap oksigen. Makin tinggi suhu maka makin sedikit oksigen yang larut (Lesmana dan Dermawan, 2001).

Hasil pengukuran $\mathrm{pH}$ air pada percobaan benih cupang bagan sebesar 5,78 - 6,48 pada semua perlakuan. Menurut Ciptanto (2010), derajat keasaman air (pH) budidaya yang memenuhi syarat adalah $5-8,5$. Sementara untuk budidaya ikan cupang adalah $\mathrm{pH} 6,5-7,5$. Pada sampling awal, nilai $\mathrm{pH}$ cenderung sama pada semua perlakuan yaitu berkisar $6,10-6,41$. Sedangkan pada sampling kedua hingga keempat nilai $\mathrm{pH}$ berfluktuasi pada semua perlakuan. Hal ini mungkin disebabkan karena pengaruh sisa pakan yang mengendap di dasar stoples. Penyiponan dilakukan hanya 1 kali dalam sehari yaitu pada sore hari, sementara pengukuran dilaksanakan sebelum dilakukan penyiponan yakni pada siang hari. Derajat keasaman dipengaruhi oleh aktivitas ikan dan organism lain, yaitu pernapasan (respirasi). Respirasi menghasilkan $\mathrm{CO}_{2}$ yang mengakibatkan $\mathrm{pH}$ menurun.

\section{KESIMPULAN DAN SARAN}

\section{Kesimpulan}

Berdasarkan hasil penelitian yang telah dilakukan, maka dapat disimpulkan bahwa pemberian berbagai jenis pakan memberikan pengaruh beda nyata terhadap pertumbuhan benih cupang. Pertumbuhan berat mutlak tertinggi yakni pada benih yang diberi perlakuan B (Tubifex sp. sclama 4 minggu). Pertumbuhan panjang mutlak tertinggi yaitu pada benih yang diberi perlakuan E (Daphnia sp. selama 2 minggu dan pakan buatan selama 2 minggu).

\section{Saran}

Dalam kegiatan pertumbuhan berat ikan cupang berumur 30 hari -58 hari disarankan tetap menggunakan pakan alami untuk memperoleh hasil pertumbuhan benih yang terbaik, yaitu Tubifex sp. dan untuk pertumbuhan panjang bisa juga menggunakan Daphnia 
sp. yang dikombinasikan dengan pakan buatan.

\section{DAFTAR PUSTAKA}

Afrianto, E., dan E. Liviawaty, 2005. Pakan Ikan. Kanisius. Yogyakarta.

Atmadjaja, J. 2009. Cupang, Panduan Lengkap Memelihara Cupang Hias dan Cupang Adu. Pencbar Swadaya. Jakarta.

Bachtiar, Yusup. 2003. Menghasilkan Pakan Alami untuk Ikan Hias. Agromedia Pustaka. Jakarta.

Buwono, L. D. 2000. Kebutuhan Asam Amino Esensial dalam Ransum. Kanisius. Yogyakarta.

Ciptanto, S. 2010. Top 10 Ikan Aur Tawar. Lily Publisher. Yogyakarta.

Djarijah, A. S. 1995. Pakan Ikan Alami. Kanisius, Yogyakarta.

Effendi, M. 2003. Biologi Perikanan. Yayasan Pustaka Nusantara. Yogyakarta.

Fujaya, Y. 1994. Fisiologi Ikan, Dasar Pengembangan Teknologi Perikanan. Rincka Citra. Jakarta.

Khairuman dan K. Amri. 2002 Membuat Pakan Ikan Konsumsi. Agromedia Pustaka. Jakarta

Lesmana, D. S. dan Dermawan, 1. 2001. Budi Daya Ikan Hias Air Tawar Populer. Penebar Swadaya. Jakarta.

Mudjiman, A. 1999. Makanan Ikan. Penebar Swadaya. Jakarta.
Nursyams, T. 2003. Kelangstangan Hidup dan Pertumbuhan Larva Ikan Betta (Betta splendens Regan). Skripsi. Fakultas Perikanan. IPB. Bogor.

Perkasa, B. E. 2002. Solust Permasalahan Cupang: Penebar Swadaya. Jakarta.

Saanin, H. 1968. Taksonomi dan Kunti Identifikasi Ikan. Binatjipta. Bandung.

Septyani, T. 2009. Pengariht Pemberian Kombinast Pakan Alami (Tubifex sp.) dan Pakan Buatan (pelet) terhadap Pernumbuhan dan Sintasan Hithu Benih Ikan RedFin Shark (Labeo erythrurus. Fowler). Skripsi. Fakultas MIPA. UNJ. Jakarta.

Steel, R., dan J. H. Torrie. 1991. Prinsip dan Prosedur Statistika. Gramedia Pustaka Utama. Jakarta.

Sorgellos, P. and P. Lavens, 1996. Mamual on Prodictionand Use of Life Food For Aquaculture. FAO Fisheries Technical Paper. Center University of Ghent. Belgium

Weatherley, A. H. 1972. Growth and Ecology of Fish Population. Academic Press. New York. http://maswira. wordpress, com/cate gorv/ aquaculture' nutrisi-ikan/. Pengaruh Pemberian Pakan Alami terhadap Pertumbuhan dan Kelangsangan Hidup Larva Ikan Semah. (Diakses I Oktober 2011).

(http:/kingaguarior.weebly.com/pengenala n-ikan-cupang.hitml. Ikan cupang laga Bagansiapiapi. (Diakses 7 Juli 2012). 
Lampiran 1. Pertumbuhan Berat Mutlak Benih Cupang Bagan (Betta imbellis var. Sumatraensis)

\begin{tabular}{lllllll}
\hline \multirow{2}{*}{ Perlakuan } & \multicolumn{3}{c}{$\begin{array}{c}\text { Berat individu rata-rata pada } \\
\text { hari ke-(gram) }\end{array}$} & $\begin{array}{c}\text { Pertumbuhan } \\
\text { berat } \\
\text { mutlak }(\mathrm{g})\end{array}$ \\
\cline { 2 - 7 } & $\mathbf{3 0}$ & $\mathbf{3 7}$ & $\mathbf{4 4}$ & $\mathbf{5 1}$ & $\mathbf{5 8}$ & $\mathbf{0 . 2 7}$ \\
\hline A & 0.17 & 0.25 & $\mathbf{0 . 3 0}$ & 0.34 & 0.44 & $\mathbf{0 . 5 6}$ \\
B & 0.17 & 0.31 & 0.34 & 0.52 & 0.73 & $\mathbf{0 . 2 1}$ \\
C & 0.16 & 0.22 & 0.24 & 0.34 & 0.37 & $\mathbf{0 . 3 5}$ \\
D & 0.16 & 0.36 & 0.46 & 0.52 & 0.51 & $\mathbf{0 . 4 4}$ \\
E & 0.17 & 0.19 & 0.25 & 0.35 & 0.61 & \\
\hline
\end{tabular}

Keterangan :

$A=$ Pakan buatan selama 1 bulan

$\mathrm{B}=$ Tubifex sp. selama 1 bulan

$\mathrm{C}=$ Daphinia sp. selama 1 bulan

$\mathrm{D}=$ Tubifex sp. selama 2 minggu dan pakan buatan selama 2 minggu

$\mathrm{E}=$ Daphnia sp. selama 2 minggu dan pakan buatan selama 2 minggu

Lampiran 2. $\mathrm{Uji}_{\mathrm{j}}$ Anova dan uji BNJ pertumbuhan berat mutlak benih cupang bagan (Betta imbellis var. Sumatraensis)

\begin{tabular}{llllll}
\hline Sumber Keragaman & $\mathrm{db}$ & $\mathrm{JK}$ & $\mathrm{KT}$ & F-Hitung & $\mathrm{P}$ \\
\hline Perlakuan & 4 & 0,217 & 0,054 & 13,678 & 0,00 \\
Galat & 10 & 0,040 & 0,004 & & 0 \\
Total & 15 & 2.303 & & &
\end{tabular}

Keterangan : $(\mathrm{P}<0.01)$

\begin{tabular}{llll}
\hline Perlakuan & Selisih Rata-rata & Standar Eror & P \\
\hline A-B & 0,2767 & 0,05142 & 0,002 \\
A-C & 0,0633 & 0,05142 & 0,735 \\
A-D & 0,0833 & 0,05142 & 0,518 \\
A-E & 0,1667 & 0,05142 & 0,054 \\
B-C & 0,3400 & 0,05142 & 0,000 \\
B-D & 0,1933 & 0,05142 & 0,024 \\
B-E & 0,1100 & 0,05142 & 0,276 \\
C-D & 0,1467 & 0,05142 & 0,098 \\
C-E & 0,2300 & 0,05142 & 0,008 \\
D-E & 0,0833 & 0,05142 & 0,518 \\
\hline
\end{tabular}

* Berbeda nyata pada $\alpha=0,05$

**Berbeda sangat nyata pada $\alpha=0,01$

Keterangan :

$\mathrm{A}=$ Pakan buatan selama 1 bulan

$\mathrm{B}=$ Tubifex sp. selama 1 bulan

$\mathrm{C}=$ Daphnia sp. selama 1 bulan

$\mathrm{D}=$ Tubifex sp. selama 2 minggu dan pakan buatan selama 2 minggu

$\mathrm{E}=$ Daphnia sp. selama 2 minggu dan pakan buatan selama 2 minggu 
Lampiran 3. Pertumbuhan Panjang Mutlak Benih Cupang Bagan (Betta imbellis var. Sumatraensis)

\begin{tabular}{lcccccc}
\hline \multirow{2}{*}{ Perlakuan } & \multicolumn{5}{c}{$\begin{array}{c}\text { Panjang Total Rata-Rata pada } \\
\text { Hari ke-(cm) }\end{array}$} & $\begin{array}{c}\text { Pertumbuhan } \\
\text { panjang } \\
\text { mutlak (cm) }\end{array}$ \\
\cline { 2 - 6 } & $\mathbf{3 0}$ & $\mathbf{3 7}$ & $\mathbf{4 4}$ & $\mathbf{5 1}$ & $\mathbf{5 8}$ & \\
\hline A & 2.36 & 2.37 & 2.38 & 2.55 & 2.79 & $\mathbf{0 . 4 3}$ \\
B & 2.36 & 2.38 & 2.70 & 2.78 & 3.14 & $\mathbf{0 . 7 8}$ \\
C & 2.35 & 2.65 & 2.79 & 2.85 & 3.06 & $\mathbf{0 . 7 1}$ \\
D & 2.34 & 2.78 & 2.88 & 2.95 & 2.98 & $\mathbf{0 . 6 4}$ \\
E & 2.35 & 2.38 & 2.42 & 2.50 & 3.15 & $\mathbf{0 . 8 0}$ \\
\hline
\end{tabular}

Keterangan :

$A=$ Pakan buatan selama 1 bulan

$\mathrm{B}=$ Tubifex sp. selama 1 bulan

$\mathrm{C}=$ Daphnia sp, selama 1 bulan

$\mathrm{D}=$ Tubifex sp. selama 2 minggu dan pakan buatan selama 2 minggu

$\mathrm{E}=$ Daphnia sp. selama 2 minggu dan pakan buatan selama 2 minggu

Lampiran 4. Uji Anova dan $\mathrm{Uji}$ BNJ Pcrtumbuhan Panjang Mutlak Benih Cupang Bagan (Betta tmbellis var. Sumatraensis)

\begin{tabular}{|c|c|c|c|c|c|}
\hline Sumber Keragaman & $\mathrm{db}$ & JK & KT & F-Hitung & $\bar{P}$ \\
\hline Perlakuan & 4 & 0,254 & 0,064 & 3,698 & 0,043 \\
\hline Galat & 10 & 0,172 & 0,017 & & \\
\hline \multirow[t]{2}{*}{ Total } & 15 & 7,120 & & & \\
\hline & & & . & & \\
\hline Perlakuan & & Selisih Rata-rata & & Standar Eror & $\mathrm{P}$ \\
\hline$A-B$ & & 0,3467 & & 0,10708 & 0,054 \\
\hline $\mathrm{A}-\mathrm{C}$ & & 0,2767 & & 0,10708 & 0,147 \\
\hline$A-D$ & & 0,2100 & & 0,10708 & 0,348 \\
\hline$A-E^{*}$ & & 0,3567 & & 0,10708 & 0,047 \\
\hline $\mathrm{B}-\mathrm{C}$ & & 0,0700 & & 0,10708 & 0,962 \\
\hline $\mathrm{B}-\mathrm{D}$ & & 0,1367 & & 0,10708 & 0,710 \\
\hline$B-E$ & & 0,0100 & & 0,10708 & 1,000 \\
\hline $\mathrm{C}-\mathrm{D}$ & & 0,0667 & & 0,10708 & 0,968 \\
\hline $\mathrm{C}-\mathrm{E}$ & & 0,0800 & & 0,10708 & 0,940 \\
\hline$D-E$ & & 0,1467 & & 0,10708 & 0,658 \\
\hline
\end{tabular}

- Berbeda nyata pada $\alpha=0,05$

Keterangan :

A = Pakan buatan selama 4 minggu

$\mathrm{B}=$ Tubifex sp. selama 4 minggu

C $=$ Daphmia sp. selama 4 minggu

$\mathrm{D}=$ Tubifex sp. selama 2 minggu dan pakan buatan selama 2 minggu

$\mathrm{E}=$ Daphnia sp. selama 2 minggu dan pakan buatan selama 2 minggu 
Lampiran 5. Pertambahan panjang total dan pertumbuhan bobot benih ikan eupang

\begin{tabular}{ccccccc}
\hline Pcrlakuan & \multicolumn{5}{c}{$\begin{array}{c}\text { Panjang total } \\
\text { tubuh rata-rata(cm) }\end{array}$} & $\begin{array}{c}\text { Total pertambahan } \\
\text { panjang total (cm) }\end{array}$ \\
\hline A & 30 & 37 & 44 & 51 & 58 & 0.44 \\
B & 2.36 & 2.64 & 2.30 & 2.36 & 2.79 & 0.78 \\
C & 2.46 & 2.80 & 2.43 & 2.88 & 3.24 & 0.71 \\
D & 1.95 & 2.39 & 2.25 & 2.45 & 2.66 & 0.64 \\
E & 2.19 & 2.85 & 2.73 & 2.87 & 2.83 & 0.80 \\
\hline & 2.35 & 2.42 & 2.31 & 2.50 & 3.15 & \\
\hline & & & & & & Total pertambahan \\
\hline Perlakuan & 30 & 37 & 44 & 51 & 58 & 0.37 \\
& & & & & & 0.69 \\
A & 1.42 & 1.61 & 1.44 & 1.49 & 1.78 & 0.50 \\
B & 1.49 & 1.74 & 1.55 & 1.88 & 2.18 & 0.52 \\
C & 1.17 & 1.45 & 1.38 & 1.54 & 1.67 & 0.65 \\
D & 1.31 & 1.78 & 1.75 & 1.86 & 1.83 & \\
\hline E & 1.41 & 1.46 & 1.43 & 1.58 & 2.06 & \\
\hline
\end{tabular}

Keterangan :

$\mathrm{A}=$ Pakan buatan selama 1 bulan

$\mathrm{B}=$ Tubifex sp. sclama 1 bulan

$\mathrm{C}=$ Daphinia sp. sclama 1 bulan

$\mathrm{D}=$ Tubifex sp. sclama 2 minggu dan pakan buatan selama 2 minggu

$\mathrm{E}=$ Daphnia sp. selama 2 minggu dan pakan buatan selama 2 minggu

Lampiran 6. Ikan Cupang

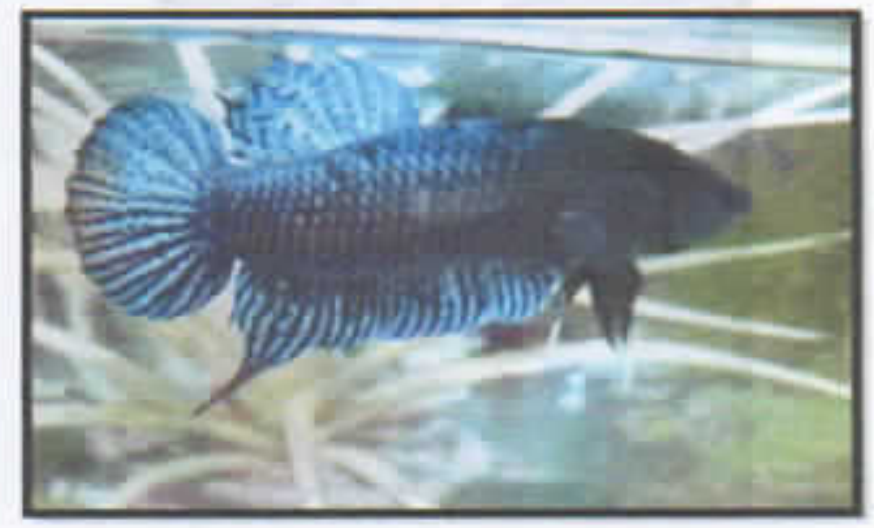

Cupang bagan adalah salah-satu jenis iloan cupang tipe adu. Nama bagan diambil dari nama Kota Bagan Siapi Api di Sumatera Utara. Sejak tahun 1900 ikan cupang bagan mulai dipertandingkan oleh masyanakat setempat. Perkembangan berjalan seiring waktu, pertukaran induk terbaik sesama peternak bagan terus berlangsung untuk bisa menghasilkan cupang adu bagan berkualitas baik dan sebagian peternak menyilangkan dengan cupang adu asal Malaysia dan cupang asal kota Medan. Cupang adu Bagan Siapi Api mulai diperhitungkan sejak 1930 1935. Akhirnya banyak generasi baru yang mengembangkan hingga saat ini (hitto:/Akingaquarior.weeblv.com/pengenalan-ikam-cupang.htmil) Ikan cupang bagan (Betta imbellis var. Sumatraensis) masih termasuk grup Teleostei (Parker dan Haswel dalam Saanin, 1968).

Lampiran Gambar 1. Ikan Cupang Bagan (Betta imbellis var. Sumatraensis) (Sumber: Perkasa, 2002). 


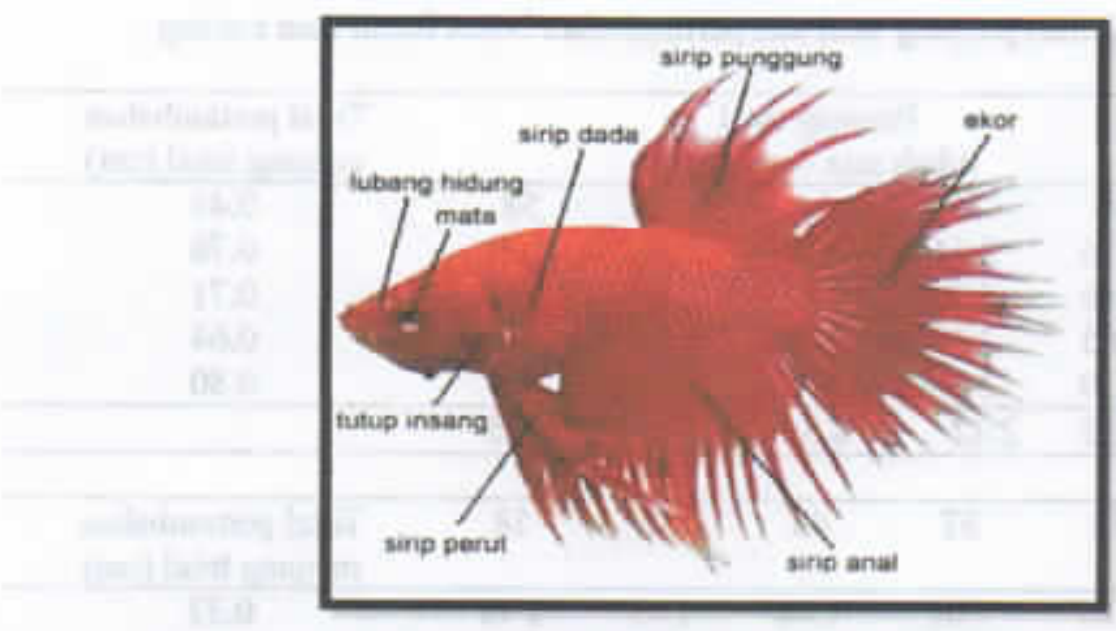

Bentuk tubuh ilean cupang secara umum cukup bervariasi, mulai dari pipih (compressed) hingga sfinder. Sisiknya terlilat besar dan kasar. Panglal elor tertilat lebar sehingga tubuhnya terilhat kokoh dan kut. Letak mata cenderung horisontal terhadap bibir. Beberapa Jenls cupang memiliki letak mata yang sedilit lebih rendah dari bibiriga. Jumbah siripnya lengkap, yaitu terdiri duri sirip pektoral (sirip) insang), sirip doral (sirip punggung), sirip ventral (sirip perut), sirip amal (sirip dubur) dan sirip laudal (sirip eloor) (Atmadjaja, 2009).

Lampiran 7. Pakan alami

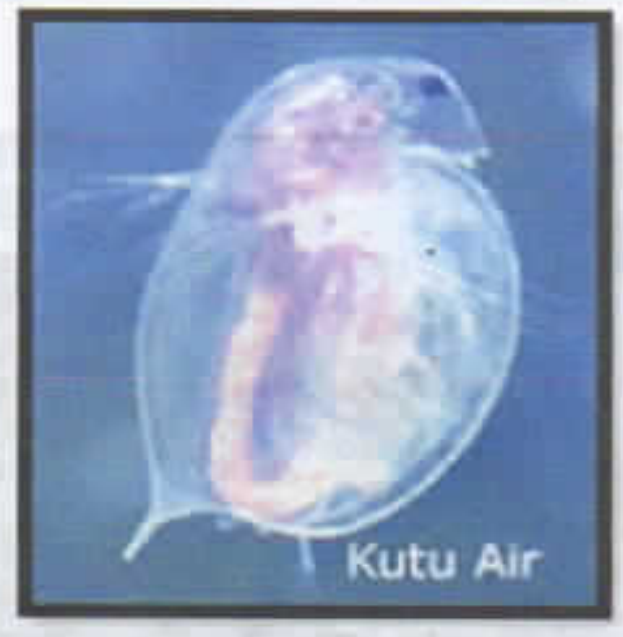

Kutu air adakh udang-udangan renik yang termasuk dalam plylum Artliropoda (Mfudjiman, 1999). Kutu air (Dephnia sp.) merupakan pakan Larva dan benilh berupa zooplankton. Pakan inl blasanya dicari di genangan alr, kolam, rawa, mapun waduk. Daphnia sp. berwarma merah, berukuran relatif besar (0,9-3,0 mm), dan banyak muncul di musim kemarau (Lesmana dan Dermaหan, 2001). Daphnia sp. mampu hidup dalam air yang kandungan oksiennya sangat rendah. Makaman loutu air (Daphnia sp.) terdiri dari bakteri, fumbuh - tumbuhan renik dan dotrifus (bahan organik yang sedang menghancur). Penganhillan malcananuya dilakukan dengan cara mengerak - gerakkan kakimga yang plpih. Gerakan kakd tersebut menimbulkan arus alr yang membawa malanan (Mludfiman, 1999). Kandungan gizi yang terdapat dakm tuhuh Daphnia sp. adabh kadar air $94,78 \%$, kadar protein $42,66 \%$, lachar lemak $8,00 \%$, kadar larbohidrat 14,10\% dan ladar abu 4,00\% (Lesmama dan Dermawan, 2001).

Lampiran Gambar 3. Daplenie sp. (Sumber: Priyambodo, 2000 dalevt hltp://maswira, wordpress.com/eafegoryfaquaculture/nutrisi-ilan/) 


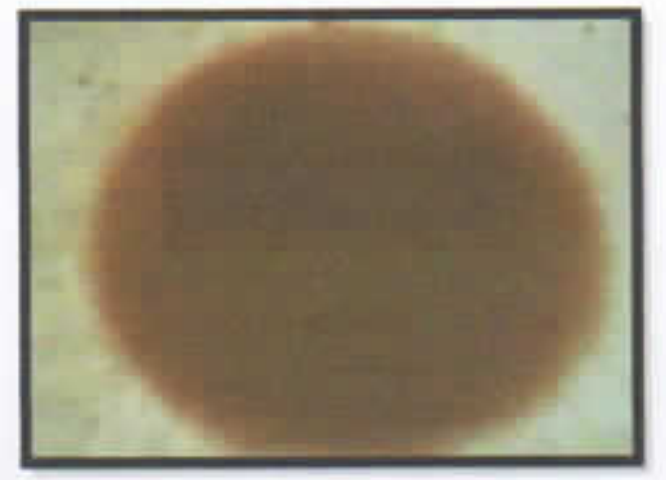

Tubifex sp. merupakan pakan yang banyak digunakan oleh petani ikan hias (Lesmana dan Dermawan, 2001) dan pakan alami yang disenangi oleh benih ilcan (Priyambodo, 2000 dalam htip://maswira wordpress, com/cuiegorv hauuculture/ nutrisi-ikan/). Cacing Tubifex sp. sering juga disebut cacing rambut loarena bentuk dan ukurannya seperti rambut. Ukurannya kecil dan ramping, panjang 1-2 cm. Warma tubuhnya kemerah-merahan. Cacing ini termasuk kedalam phylum Annelida. Tubuhnya beruas - ruas. Cacing ini memilikj saluran pencernaan. Mulutnya berupa celah kecil, terietak didaerah ujung. Saluran peneermannya berakhir pada anus yang terletak di ujung lainnya (Djarijah, 1995).

Lampiran Gumbar 4. Tubifex sp.(Sumber : Asniati, 2012)

\section{Lampiran 8. Pakan buatan}
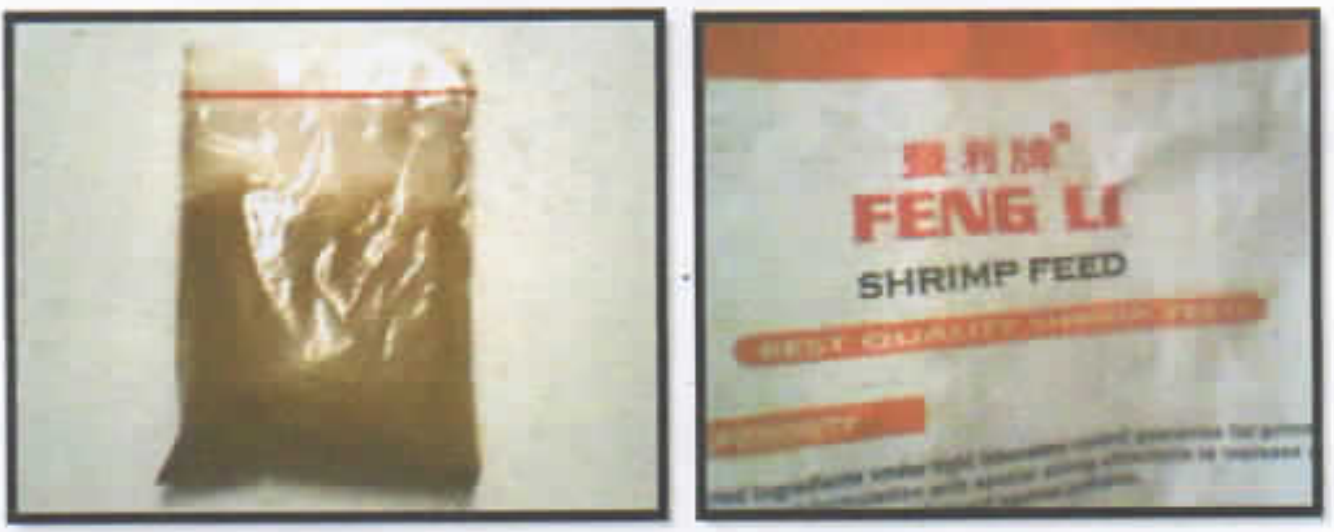

Pakan ikan buatan merupakan makanan flon yang dibuat dari campuran bahan bahan alami dan atau bahan olahan yang selanjutnya dilakukan proses pengolahan serta dibuat dalam bentuk tertentu sehingga tercipta daya tarik (merangsang) ikan untuk memakannya dengan mudah dan lahap (Djarijah, 1995). Pakan buatan berbentuk butiran yang paling banyak dikenal adalah pelet. Pelet dapat berupa moist pellet (pelet basah) dan dry pellet (pelet kering). Pelet digunakan sebagai pakan ikan dewasa karena butirannya mempunyai bentuk dan ukuran yang besar. Ada juga pakan berbentuk tepung dan cramble yang biasa dipakai untuk pakan ikan hias. Crumble biasanya merupakan pecahan dari pelet (Khairuman, 2002). Pakan buatan ini bamyak dijual di pasaran dalam berbagai bentuk, ukuran dan kualitas. Penggunaan pakan buatan sangat praktis dan dapat disimpan lama, namun pemantauan kualitas air sangat diperlukan. Pemberian pakan buatan sebaiknya terbatas, cukup untuk kebutuhan Ikan, lebih baik sering memberikan pakan buatan dengan jumlah sedikit dibandingkan jumbah banyak sekaligus tanpa dihabiskan ikan (Lesmana dan Dermawan, 2001). Bentuk pakan buatan sangat beragam, yakni berupa pakan basah, pakan kering, dan pakan lembab.

Lampiran Gambar 5. Pakan Buatan Kering Jenis Crumble (Sumber ; Asniati, 2012) 